\title{
Reduced susceptibility to disinfectants of Acinetobacter baumannii biofilms on glass and ceramic
}

\author{
Tomislav Ivanković ${ }^{1}$, Ivana Goić-Barišić ${ }^{2}$, and Jasna Hrenović ${ }^{1}$ \\ University of Zagreb, Faculty of Science, Department of Biologyl, Zagreb, University of Split School of Medicine, \\ Hospital Centre Split, Department of Clinical Microbiology², Split, Croatia
}

[Received in February 2017; Similarity Check in February 2017; Accepted in June 2017]

\begin{abstract}
The aim of this study was to determine the susceptibility of hospital and environmental Acinetobacter baumannii isolate biofilms on ceramics and glass to common disinfectants benzalkonium chloride and chlorhexidine. For this purpose we developed a new method for biofilm cultivation and quantification on ceramics. The biofilm bacteria were more resistant to disinfectants than the planktonic populations, as more than $50 \%$ of the biofilm population and none of the planktonic population survived 5-minute exposure. Furthermore, biofilm populations on ceramic tiles were significantly more resistant than those on glass coverslips, even though the amount of biofilm was practically the same on ceramics and glass. The reason for reduced susceptibility of $A$. baumannii biofilms on ceramics may be related to surface/disinfection interactions. Our findings suggest that biofilms on ceramic surfaces can be an important source of $A$. baumannii infection in hospital environments.
\end{abstract}

KEY WORDS: benzalkonium chloride; chlorhexidine, hospital infections, surfactants

Acinetobacter baumannii has emerged as an increasingly important pathogen worldwide. Over the last decade, this bacterium has become one of the most prominent causes of hospital infections (1-4). On 27 April 2017, the Web of Science $^{\mathrm{TM}}$ listed 5,881 scientific reports (articles, books, reviews, and abstracts) published between 2010 and 2017 which had Acinetobacter baumannii in the title. They covered the issues of antibiotic resistance, transmission, biofilm formation, environmental emergence, susceptibility to disinfectants, and so on.

A. baumannii infections owe their persistence to multidrug resistance and the ability to form biofilms $(2,5)$, which protect the bacteria from disinfectants and/or desiccation on abiotic surfaces (6-10).

Reports have shown that commonly used disinfectants, such as $70 \%$ ethanol, chlorhexidine, sodium hypochlorite, or quaternary ammonium compounds are $100 \%$ effective against $A$. baumannii isolates when used at concentrations recommended by the manufacturer. When used diluted, however, disinfectants are not as effective (11-13). In a report by Lanjri et al. (12), chlorhexidine digluconate was effective against all tested isolates $(\mathrm{N}=81)$ at the concentration recommended by the manufacturer $(0.5 \%)$, but six isolates showed resistance to 1:10 dilution and 47 to 1:100 dilution. All of these reports underline that the high persistence of A. baumannii hospital infections is greatly owed to non-compliance with manufacturer instructions.

Correspondence to: Tomislav Ivanković, University of Zagreb, Faculty of Science, Department of BiologyRooseveltov trg 6, 10000 Zagreb

E-mail: tomislavivankovic@biol.pmf.hr
Another important reason for its increased resistance to disinfection are biofilms on abiotic surfaces (2).

Babaei et al. (14) suggest that the reduced susceptibility of A. baumannii to disinfectants correlates with its multidrug resistance, as they found genes encoding resistance to common disinfectants such as quaternary ammonium compounds or chlorhexidine in A. baumannii hospital isolates. Kawamura-Sato et al. (15) also found that hospital Acinetobacter spp. isolates with reduced susceptibility to disinfectants showed higher multidrug resistance to ceftazidime, ciprofloxacin, and amikacin. A similar finding was confirmed by an Egyptian group examining A. baumannii isolates taken in an intensive care unit (16). Some authors point to cross-resistance, while others find no significant correlation or evidence thereof $(17,18)$.

The aim of our study was to determine the susceptibility of various $A$. baumannii isolates in planktonic and biofilm form to the two most common hospital disinfectants and compare it to their antibiotic susceptibility profiles. We started from the hypothesis that biofilm would reduce susceptibility but then also wanted to see what this would mean in practice. To that end we compared biofilm formation on ceramic tiles with that on standard laboratory glass, assuming that ceramic tiles are a rather common abiotic surface in hospitals. Our study design brings the following novelties:

-the tested bacteria included the reference ATCC strain, hospital isolates, and environmental isolates found outside hospital settings in municipal wastewater. So far, the susceptibility to disinfectants or the biofilm-forming 
capacity of $A$. baumannii environmental isolates has not been reported;

-A. baumannii biofilm was quantified on commercial bathroom ceramic tiles as potential reservoirs of $A$. baumannii in hospitals. For this purpose we developed a novel quantification procedure;

-the biofilm-forming capacity of the isolates was quantified by counting viable cells instead of using the gentian violet biofilm assay which does not distinguish dead or non-viable from viable cells as they are counted.

\section{MATERIALS AND METHODS}

\section{Bacteria}

Eight isolates of Acinetobacter baumannii were used in the experiments: the ATCC strain 19606, four hospital, and three environmental isolates (Table 1). All were stored in a Microbank ${ }^{\mathrm{TM}}$ culture storage system (Pro-Lab Diagnostics, Toronto, Canada) at $-80{ }^{\circ} \mathrm{C}$. Before each experiment the bacteria were grown on nutrient agar plates (Biolife Italiana, Milano, Italy) containing deionised water, $3 \mathrm{~g} \mathrm{~L}^{-1}$ of beef extract, $5 \mathrm{~g} \mathrm{~L}^{-1}$ of peptone, and $20 \mathrm{~g} \mathrm{~L}^{-1}$ of agar at $42{ }^{\circ} \mathrm{C}$ for $16 \mathrm{~h}$.

The environmental isolates were collected from influent and effluent wastewater of a Zagreb treatment plant in 2014 as described in detail by Hrenović et al. (19). Hospital isolates were collected from clinical specimens and stored at the University Hospital Centre Split as described earlier by Goić-Barišić et al. (20).

\section{Determination of minimal bactericidal concentration}

The minimal bactericidal concentrations (MBC) of benzalkonium chloride (BAC, Sigma-Aldrich, Taufkirchen, Germany) and chlorhexidine digluconate $(\mathrm{CH}$, SigmaAldrich, Taufkirchen, Germany) were determined for all eight isolates using a slightly modified dilution-neutralisation method $(21,22)$. For each isolate we prepared a bacterial suspension of $10^{5} \mathrm{CFU} \mathrm{mL}^{-1}$ (using 1:10 serial dilutions) in nutrient broth (Biolife Italiana, Milano, Italy) and distributed $0.5 \mathrm{~mL}$ of the suspension to a series of sterilised Eppendorf tubes (LLG International, Meckenheim,
Germany). Then we added $800 \mathrm{mg} \mathrm{L}^{-1}$ of $\mathrm{BAC}$ or $\mathrm{CH}$ to the first tube and halved the $\mathrm{BAC}$ or $\mathrm{CH}$ concentrations for each following tube until the final concentration of $3.125 \mathrm{mg} \mathrm{L}^{-1}$. After 1,5 , and $10 \mathrm{~min}$ of contact, we inoculated $10 \mu \mathrm{L}$ from each vial on nutrient agar plates containing Tween 20 as a neutralisation agent $\left(1 \mathrm{~g} \mathrm{~L}^{-1}\right.$, the Tween 20 was added to cooled nutrient agar after autoclaving). The plates were set for incubation at $42{ }^{\circ} \mathrm{C}$ for $24 \mathrm{~h}$, examined, and the lowest $\mathrm{BAC}$ or $\mathrm{CH}$ concentration with no growth was marked as MBC. The procedure for $\mathrm{MBC}$ determination was done in duplicate.

\section{Biofilm formation on glass coverslips}

To quantify biofilm formation of $A$. baumannii isolates and test the efficiency of BAC and $\mathrm{CH}$ against the biofilm bacteria we used the following procedure (Figure 1):

\section{Step 1}

Sterilised $\left(110{ }^{\circ} \mathrm{C} / 6 \mathrm{~h}\right)$ glass cover slips $(20 \times 20 \mathrm{~mm}$, Vitrognost, Zagreb, Croatia) were immersed in $20 \mathrm{~mL}$ of nutrient broth in large, $50 \mathrm{~mL}$ polypropylene Falcon tubes (LLG International, Meckenheim, Germany). One millilitre of bacterial suspension $\left(10^{8} \mathrm{CFU} \mathrm{mL} \mathrm{mL}^{-1}\right)$ was added to the tube and incubated in an orbital shaker $(150 \mathrm{rpm}$, Biosan, Latvia) at $30{ }^{\circ} \mathrm{C}$ for $72 \mathrm{~h}$. The tubes were capped but not tightly sealed to allow aerobic conditions. After $72 \mathrm{~h}$, the slides were taken out and gently washed with $10 \mathrm{~mL}$ of sterile saline $(0.3 \% \mathrm{NaCl})$ to remove loose biomass. Two glass cover slips were tested in parallel for each experiment.

Step 2

The glass cover slips with formed biofilm were completely immersed in $10 \mathrm{~mL}$ of nutrient broth in Falcon tubes for $5 \mathrm{~min}$. Nutrient broth contained the previously determined $\mathrm{MBC}$ concentration for each isolate and disinfectant. For example, the MBC of BAC for isolate EU1 was $25 \mathrm{mg} \mathrm{L}^{-1}$, so the glass slip with the EU1 biofilm was immersed in nutrient broth containing $25 \mathrm{mg} \mathrm{L}^{-1}$ of BAC. The idea was to test whether the bacteria in biofilm would survive the MBC that had killed $100 \%$ of its planktonic population.

Table 1 A. baumannii isolates used in the experiments

\begin{tabular}{lc}
\hline Designation & Origin \\
\hline ATCC & ATCC 19606 strain \\
\hline EU1 & Hospital isolate, UHCS, 2004 \\
\hline EU2 & Hospital isolate, UHCS, 2009 \\
\hline ST4 & Hospital isolate, UHC, 2009 \\
\hline ST10 & Hospital isolate, UHC, 2009 \\
\hline IN12 & Environmental isolate, WWTP of Zagreb, 2014, influent \\
\hline IN21 & Environmental isolate, WWTP of Zagreb, 2014, influent \\
\hline EF4 & Environmental isolate, WWTP of Zagreb, 2014, effluent \\
\hline
\end{tabular}

UHCS - University Hospital Centre Split, Croatia; WWTP Zagreb - Central wastewater treatment plant of the city of Zagreb, Croatia 


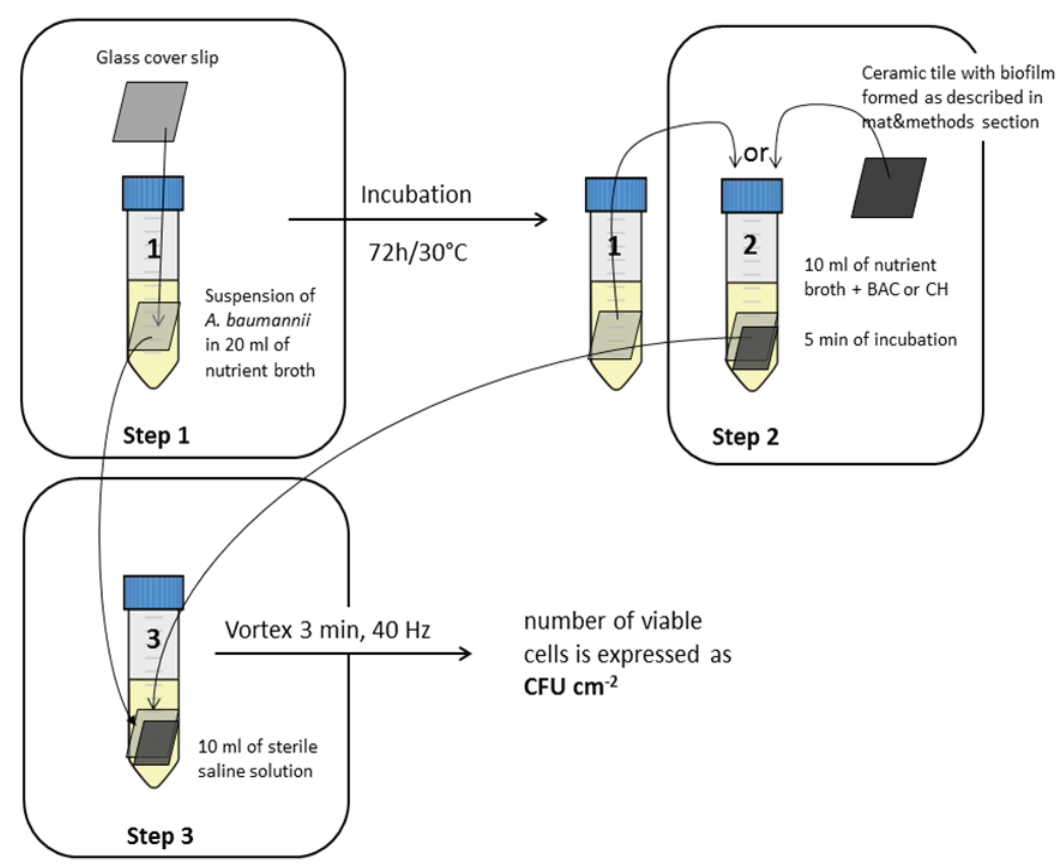

Figure 1 Schematic of the experiment to test the efficiency of disinfectants against A. baumannii biofilms formed on glass cover slips or ceramic tiles; $B A C$ - benzalkonium chloride; $\mathrm{CH}$ - chlorhexidine digluconate

Step 3

After $5 \mathrm{~min}$, the slip was transferred to another Falcon tube containing $10 \mathrm{~mL}$ of sterile saline. The tube was tightly sealed and shaken in a vortex shaker $(40 \mathrm{~Hz})$ for $3 \mathrm{~min}$ to detach the bacteria from the cover slips and let them float as planktonic cells in the solution. One millilitre of sample was taken, diluted serially, and $0.1 \mathrm{~mL}$ was inoculated on nutrient agar plates. After incubation at $42{ }^{\circ} \mathrm{C}$ for $24 \mathrm{~h}$, the colonies were counted and the number of bacteria was reported as CFU per $\mathrm{cm}^{2}$.

The above procedure for biofilm detachment and enumeration (Step 3) was validated by determining the number of the bacteria that remained attached to the cover slips, as follows: the slip from which the biofilm was detached was gently washed with sterile saline, transferred to a Falcon tube containing $10 \mathrm{~mL}$ of sterile saline, vortexed again for $3 \mathrm{~min}$, and the number of the remaining bacteria counted in the solution. Validation was made for the isolates ATCC, ST10, and EF4 (two glass slips for each). Seeing that the number of the remaining bacteria ranged from 1.4 to $7.3 \times 10^{2} \mathrm{CFU} \mathrm{cm}^{-2}$, and that the count of all tested isolates detached from the cover slips in the first pass was in the $10^{5}-10^{7} \mathrm{CFU} \mathrm{cm} \mathrm{cm}^{-2}$ range, we considered the number of the remaining bacteria insignificant and the counting procedure valid.

The biofilm-forming potential of the rest of the isolates was determined using the same procedure as described above, but Step 2 was skipped.

\section{Biofilm formation on ceramic tiles}

For the experiment we purchased one randomly chosen bathroom mosaic ceramic tile that consists of many miniature, $2 \times 2 \mathrm{~cm}$ tiles. We separated the miniature tiles and thoroughly washed with soap and water. Tile dimensions corresponded to the glass cover slips in length and width, but not in thickness. To grow biofilm on the upper surface alone, we developed the following procedure: the tiles were first sterilised by dry heat at $110^{\circ} \mathrm{C}$ for $6 \mathrm{~h}$. Then we poured $50 \mathrm{~mL}$ of agar solution (BactoAgar, Biolife Italiana, Milano, Italy; $20 \mathrm{~g} \mathrm{~L}^{-1}$, autoclaved at $121^{\circ} \mathrm{C}$ for $20 \mathrm{~min}$ ) into a $150 \mathrm{~mm}$ plastic petri dish (Anicrin, Scorze, Italy) and immersed the tiles top up in the agar while it was still fluid, making sure that it does not cover the upper, ceramic surface. When the agar solidified, only the upper surface of the tile was exposed while the bottom and the sides were immersed in the agar. One petri dish can accommodate about 10 tiles. Then we inoculated $70 \mathrm{~mL}$ of nutrient broth with an $A$. baumannii isolate $\left(10^{7} \mathrm{CFU} \mathrm{mL}^{-1}\right)$ and poured the whole volume in the petri dish to cover the exposed ceramic surface (Figure 2). The dish content was then incubated on an orbital shaker (OS-10, Biosan, Riga, Latvia) to ensure very gentle mixing (50 rpm) at $30{ }^{\circ} \mathrm{C}$ for $72 \mathrm{~h}$. After the incubation, each miniature tile was gently removed from the agar with sterile tweezers and washed with $10 \mathrm{~mL}$ of sterile saline. Afterward, the tiles were treated in the same way as glass cover slips. The experiment was done in duplicate.

\section{Susceptibility of biofilms to disinfectants}

Biofilm susceptibility to BAC and $\mathrm{CH}$ was calculated by dividing the bacterial counts after exposure to disinfectants with the baseline bacterial counts before exposure $\left(\log \mathrm{CFU} \mathrm{cm} \mathrm{cm}^{-2}\right)$ and is expressed as the percentage of survival. 

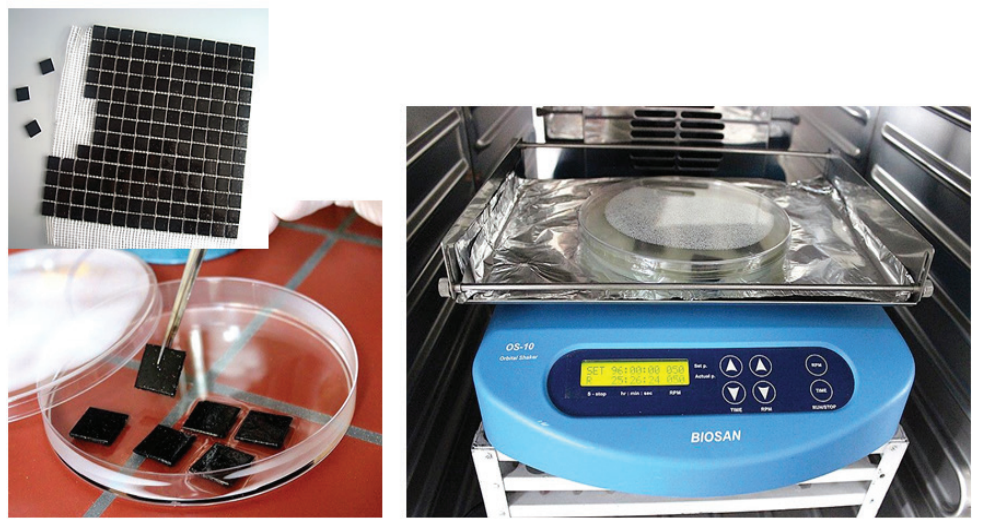

Petri dish $150 \mathrm{~mm}$

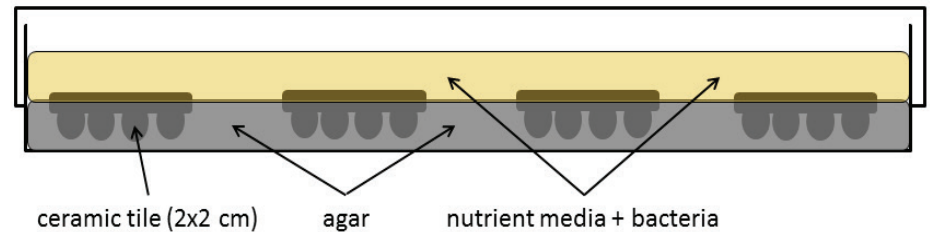

Figure 2 Experimental setup for growing biofilm on ceramic tiles (courtesy of $R$. Horvat)

\section{Susceptibility to antibiotics}

The susceptibility of $A$. baumannii isolates to carbapenems (meropenem and imipenem), fluoroquinolones (ciprofloxacin and levofloxacin), aminoglycosides (tobramycin, gentamicin, and amikacin), folate pathway inhibitors (trimethoprim and sulfamethoxazole), and a polymyxin (colistin) was determined from minimal inhibitory concentrations (MIC) obtained on Vitek2ASTXN05 and AST-N233 testing cards (bioMerieux, Marcyl'Étoile, France). Colistin resistance was confirmed with the gradient dilution E-test (AB Biodisk, bioMerieux, Marcy-l'Étoile, France). The tested antibiotic categories and obtained MICs were chosen and interpreted according to the criteria set by the European Committee on Antimicrobial Susceptibility Testing (EUCAST) (23).

\section{Statistical analysis}

The count of the colony-forming units (CFUs) was logarithmically transformed to normalise distribution and equalise variances. For statistical analysis we used the Statistica v. 12 (StatSoft, Tulsa, OK, USA). The samples were compared using one-way analysis of variance (ANOVA) with post hoc Duncan's new multiple range test and correlation analysis. Statistical significance was set at $\mathrm{p}<0.05$.

\section{RESULTS}

\section{Susceptibility of planktonic bacteria to disinfectants}

The efficiencies of the tested disinfectants were the same regardless of the contact time, with some exceptions. The exceptions, where MBC was lower after 5 min than after
$1 \mathrm{~min}$ of contact, were (isolate/disinfectant): ST10/CH, IN12/CH, IN21/BAC, and EF4/BAC (Figure 3). Only the ST4/BAC combination achieved maximum efficiency after 10 min of contact.

EU2 and ST4 showed the highest resistance to both disinfectants, while EF4 showed the highest resistance to $\mathrm{CH}$.

BAC was more effective than $\mathrm{CH}$ against five isolates (ATCC, EU1, IN12, IN21, EF4) and CH against one isolate (ST10).

There was no significant correlation $(\mathrm{R}=-0.25, \mathrm{p}>0.05)$ between the efficiency of disinfectants and the origin of $A$. baumannii isolates (hospital or environmental).

\section{Susceptibility of biofilms to disinfectants (glass)}

The ST4 and ST10 isolates stood out with their biofilmforming capacity (Figure 4) compared to other isolates $(\mathrm{p}<0.05)$.

As expected, the bacteria in biofilms were less susceptible to disinfectants. While the planktonic populations were completely inactivated by $\mathrm{MBCs}$, in biofilms more than $50 \%$ of the population survived 5-minute exposure to disinfectants (Figure 5). The exceptions were the EU2/BAC, EU2/CH, and EF4/BAC isolate/disinfectant combinations, where bacteria were completely inactivated even in the biofilm. These results were not included in the statistical analysis, as they were considered extremes.

Statistically, the survival of the bacteria in biofilm correlated significantly ( $\mathrm{r}=0.66)$ with the biofilm-forming capacity in the experiments with BAC but not with $\mathrm{CH}$. In other words, the bacteria that formed more biofilm were more resistant to $\mathrm{BAC}$ but not to $\mathrm{CH}$. 


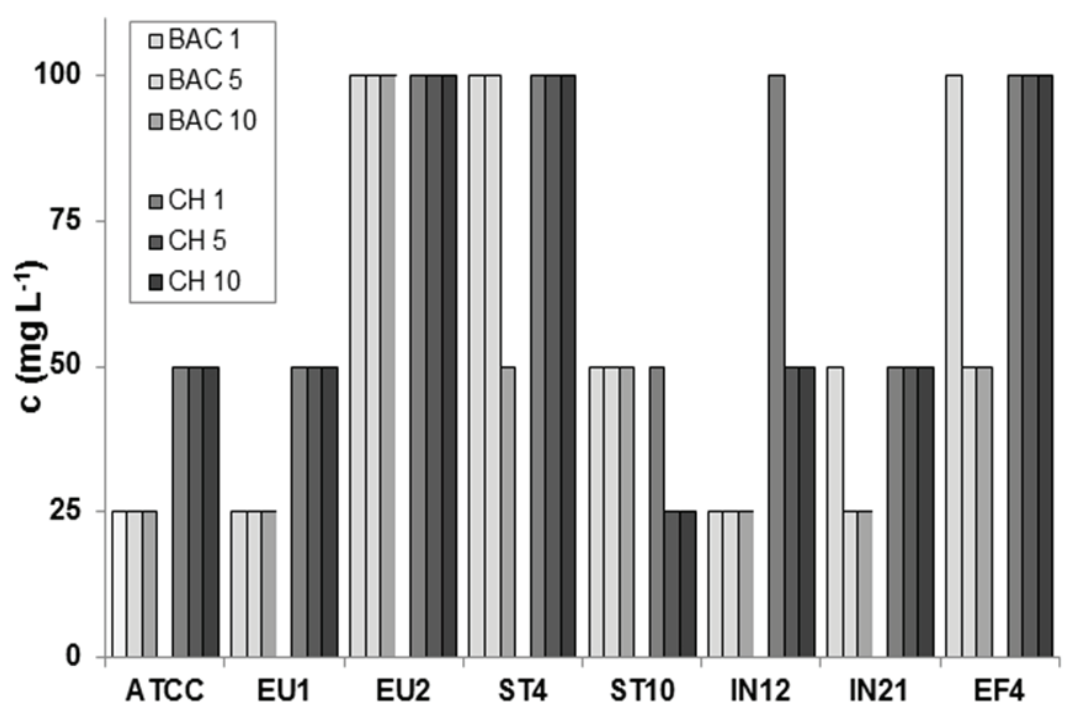

Figure 3 Minimal bactericidal concentrations of benzalkonium chloride (BAC) and chlorhexidine digluconate (CH) against environmental and hospital isolates of A. baumannii after 1,5, and 10 min of contact

The resistance of the isolates in biofilms correlated significantly with the respective MBCs in the experiments with $\mathrm{BAC}$, but this correlation was inverse with $\mathrm{CH}$. In other words, isolates that were more resistant to $\mathrm{BAC}$ as planktonic were also more resistant in biofilm, but isolates that were more resistant to $\mathrm{CH}$ as planktonic were less resistant in biofilm.

\section{Susceptibility of biofilms to disinfectants (ceramics)}

Our hypothesis was that the bacteria grown on ceramic tiles would be more resistant to disinfectants than the ones grown on glass. This is why we selected the two most susceptible isolates from the glass experiment to test our hypothesis, namely EU2 and EF4 (both exposed to BAC), whose biofilms were destroyed by the disinfectant. We assumed that the results obtained for the most susceptible isolates would hold true for all of the remaining isolates.

The number of unexposed viable bacteria of the EU2 and EF4 isolates in the biofilm grown on ceramic tiles was almost identical to glass (see Figure 4, EU2cr and EF4cr). However, when exposed to BAC, their survival on ceramic tiles was dramatically higher. From glass, where it was zero, it rose to $70 \%$ (EU2) and $81 \%$ (EF4) on ceramics (Figure 6). Furthermore, the EU2 biofilm survival was the same even when exposed to $200 \mathrm{mg} \mathrm{L}^{-1}$ of BAC (Figure 6), and EF4 survived even at $500 \mathrm{mg} \mathrm{L}^{-1}$, which is 10 times its MBC.

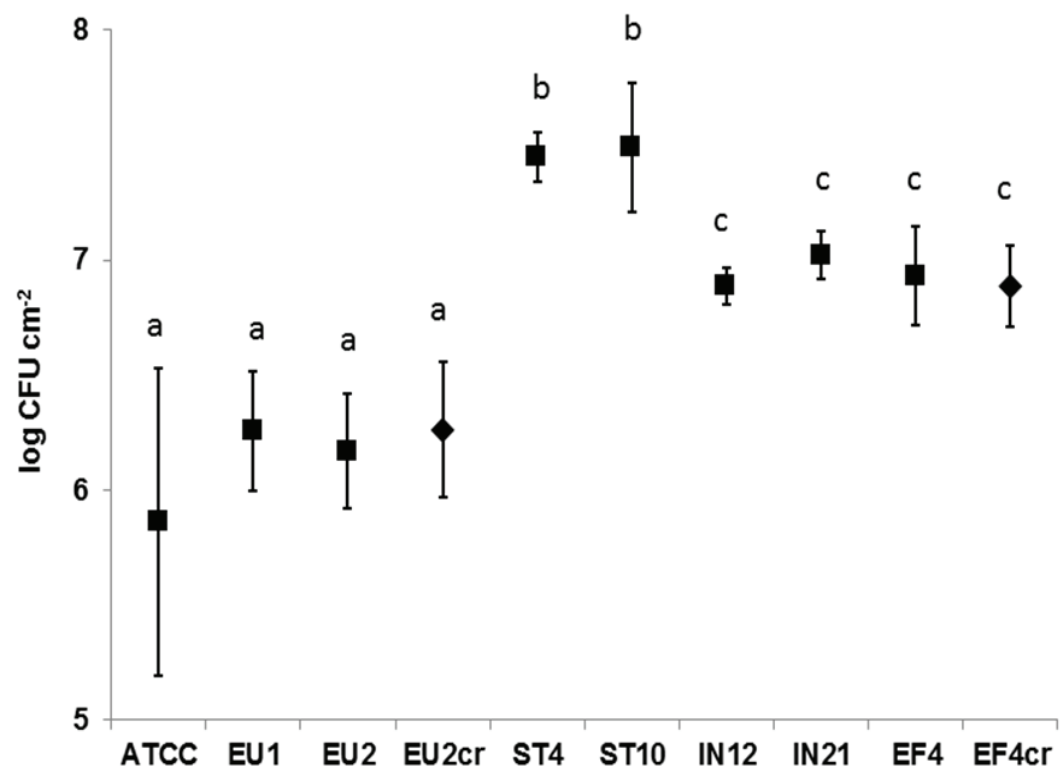

Figure 4 Viable bacteria counts (mean $\pm S D$ of duplicates) in biofilms grown for $72 \mathrm{~h}$ on glass cover slips or ceramic tiles (EU2cr and EF4cr); $a$ - significantly different from $b$ and $c ; b$ - significantly different from $c(p<0.05)$ 


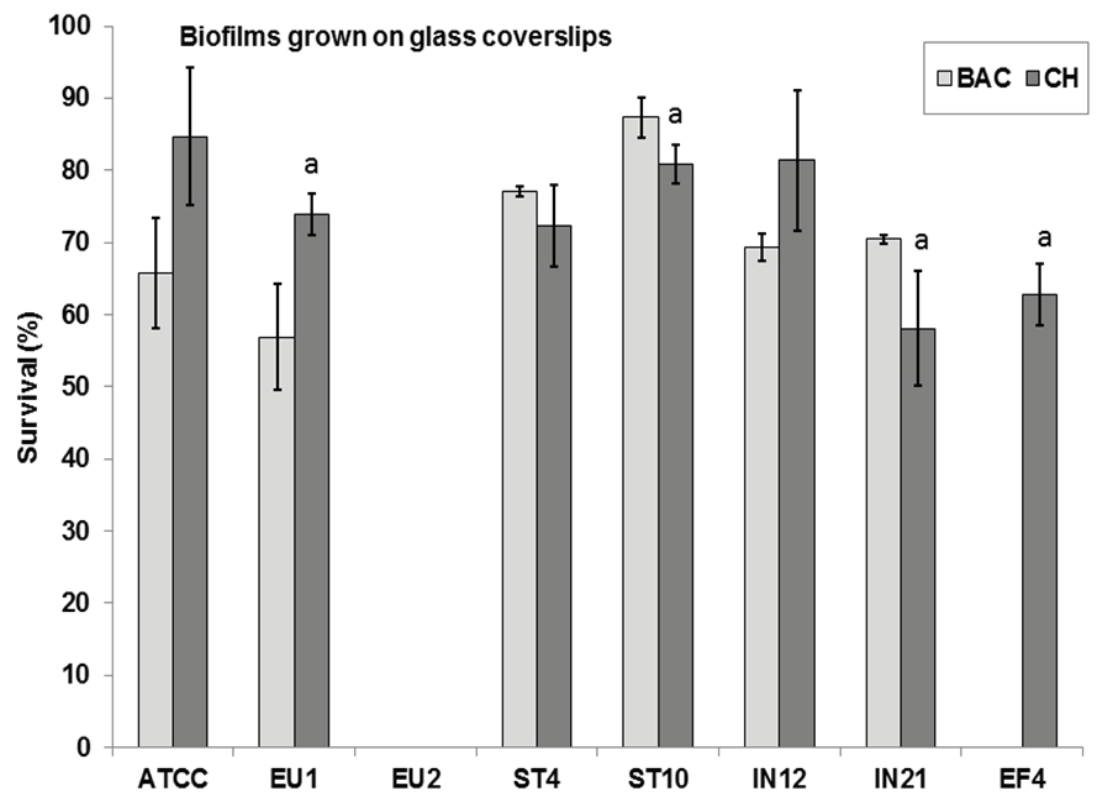

Figure 5 Survival (mean $\pm S D$ of duplicates) of bacteria in biofilms grown on glass cover slips after 5 min of exposure to benzalkonium chloride $(B A C)$ and chlorhexidine digluconate $(\mathrm{CH})$ at their respective $M B C$ concentrations; a - significantly different from $B A C$ $(p<0.05)$

Susceptibility of A. baumannii isolates to antibiotics

According to the criteria for describing resistance profiles, adopted from Magiorakos et al. (24), three isolates were classified as sensitive (susceptible to all or $\geq 3$ antimicrobial categories) and five isolates were classified as extensively drug-resistant (not susceptible to at least one agent in all but two or fewer antimicrobial categories) (Table 2). We found no significant differences in MBCs between these two groups (sensitive and extensively drug-resistant) regardless of the disinfectant (Figure 7) nor did we find significant differences in their biofilm-forming capacity.

\section{DISCUSSION}

\section{Planktonic bacteria}

At concentrations intended for commercial use (>10,000 $\mathrm{mg} \mathrm{L}^{-1}$ ) both tested disinfectants were completely effective to all $A$. baumannii isolates (tested, but data not shown).

A. baumannii spp. showed high intra-species variability in susceptibility to disinfectants. The differences in MBCs were up to fourfold between the isolates, and similar findings for $A$. baumannii and other bacteria have already

Table 2 Minimum inhibitory concentrations (MIC) of antibiotics for A. baumannii isolates

\begin{tabular}{|c|c|c|c|c|c|c|c|c|c|c|}
\hline \multirow{3}{*}{ Isolate } & \multicolumn{9}{|c|}{ MIC mg L $\left.\mathrm{L}^{-1}\right)$} & \multirow{3}{*}{$\begin{array}{l}\text { Antimicrobial } \\
\text { resistance } \\
\text { profile }\end{array}$} \\
\hline & \multicolumn{2}{|c|}{ Carbapenems } & \multicolumn{2}{|c|}{ Fluoroquinolones } & \multicolumn{3}{|c|}{ Aminoglycosides } & \multirow{2}{*}{$\begin{array}{c}\begin{array}{c}\text { Folate } \\
\text { pathway } \\
\text { inhibitors }\end{array} \\
\text { SXT }\end{array}$} & \multirow{2}{*}{$\begin{array}{c}\text { Polymyxins } \\
\text { CST } \\
\end{array}$} & \\
\hline & MEM & IPM & CIP & LVX & TOB & GEN & AMK & & & \\
\hline $\begin{array}{l}\text { ATCC } \\
19606\end{array}$ & 0.125 & 0.25 & 0.25 & 0.12 & 0.5 & 0.5 & 0.25 & 20 & 0.064 & $\mathrm{~S}$ \\
\hline EU1 & $8^{1}$ & 2 & $4^{\mathrm{R}}$ & $8^{R}$ & 2 & $8^{\mathrm{R}}$ & $32^{\mathrm{R}}$ & 16 & 0.5 & XDR \\
\hline EU2 & $128^{\mathrm{R}}$ & $32^{\mathrm{R}}$ & $16^{\mathrm{R}}$ & $8^{R}$ & 2 & $32^{\mathrm{R}}$ & $64^{\mathrm{R}}$ & 16 & 0.19 & XDR \\
\hline ST4 & 1 & 0.5 & $2^{\mathrm{R}}$ & $1^{\mathrm{I}}$ & 1 & $8^{\mathrm{R}}$ & 2 & 16 & 0.5 & S \\
\hline ST10 & $64^{\mathrm{R}}$ & $32^{\mathrm{R}}$ & $8^{R}$ & $4^{\mathrm{R}}$ & 2 & $16^{\mathrm{R}}$ & $32^{\mathrm{R}}$ & 8 & 0.19 & XDR \\
\hline IN12 & $>16^{\mathrm{R}}$ & $>16^{\mathrm{R}}$ & $4^{\mathrm{R}}$ & $>8^{\mathrm{R}}$ & $8^{\mathrm{R}}$ & $>16^{\mathrm{R}}$ & 4 & 16 & 0.5 & XDR \\
\hline IN21 & 0.25 & 0.25 & 0.25 & 0.12 & 1 & 1 & 2 & 20 & 0.5 & $\mathrm{~S}$ \\
\hline $\mathrm{EF} 4$ & $>32^{\mathrm{R}}$ & $>32^{\mathrm{R}}$ & $4^{\mathrm{R}}$ & $>8^{\mathrm{R}}$ & $>16^{\mathrm{R}}$ & $>16^{\mathrm{R}}$ & $16^{\mathrm{I}}$ & 32 & 0.75 & XDR \\
\hline
\end{tabular}




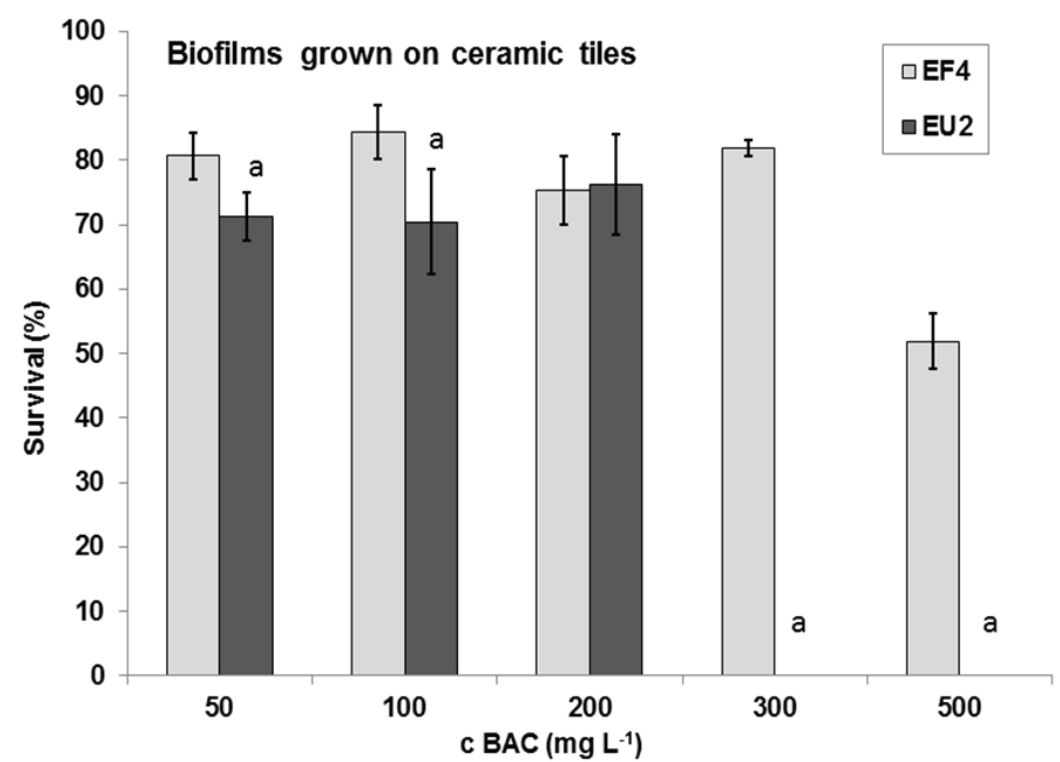

Figure 6 Survival (mean $\pm S D$ of duplicates) of bacteria in biofilms grown on ceramic tiles after 5 min of exposure to benzalkonium chloride (BAC) at various concentrations; a - significantly different from EF4 ( $p<0.05)$

been reported elsewhere $(15,25)$. Our findings, however, suggest that this variability does not depend on the origin of the isolate (hospital or environmental) but is probably intrinsic to the strain.

\section{Biofilm}

The A. baumannii isolates in the biofilm were less susceptible to disinfectants than the planktonic bacteria. However, in our experiments more biofilm did not necessarily mean greater resistance to disinfectants, as this proved true only for BAC but not for $\mathrm{CH}$. Considering the relatively small number of isolates tested in our study, this correlation can only be considered indicative. Just to compare, no correlation was found between the capacity to produce biofilm and the MICs of quaternary ammonium compounds when $E$. coli was tested (22).

However, it is beyond doubt that biofilms did provide protection against disinfectants; at concentrations that eradicated the planktonic populations, the bacterial survival in biofilms formed on glass was over $50 \%$ even after $5 \mathrm{~min}$ of contact. The glass used in this study is probably the least suitable substrate for biofilm formation; it is hydrophilic, inert, and negatively charged, all of the properties that disfavour biofilm formation. For illustration, hospital isolates of $A$. baumannii produced significantly more biofilm on polycarbonate and polypropylene than on glass (26).

On ceramics, however, biofilm formation was no greater than on glass, much to our surprise, as ceramic tiles are not as abiotic, smooth, and inert as glass. Yet, the survival of the EU2 and EF4 isolates improved dramatically. Biofilms grown on ceramics were up to 10 times more resilient to $\mathrm{BAC}$ than the ones grown on glass. This raises the question how is the material on which biofilm is formed related to the efficiency of a disinfectant. Egington et al. (27) found a correlation between the two, as Staphylococcus epidermidis biofilms were more resistant to disinfectants when grown on stainless steel than on glass. Lehtola et al. (28) reported that chlorine was far less effective against bacterial biofilms in copper than in polyethylene pipes. No one so far, however, has run experiments to elucidate why BAC is less effective when used on ceramics than on glass. Experiments that would determine surface roughness, specific area, or contact angle would surely help to explain our findings. What is evident, for now, is that ceramics could be an important reservoir of viable $A$. baumannii in hospital environments. Hospital showers have already been proposed as possible habitats of $A$. baumannii $(29,30)$, and our findings shed some light on the possible reasons why. They also point to the need to review and improve disinfection of ceramic surfaces.

\section{Antibiotic susceptibility and resistance to disinfectants}

The isolates used in this study were grouped as sensitive (three isolates) and extensively drug-resistant (XRD, six isolates). The sensitive ones were the ATCC strain, one hospital and one environmental isolate. As the sensitive group did not differ in MBCs of either disinfectant from the XRD group, there was no evidence that multidrugresistant (MDR) A. baumannii strains were also more resistant to the tested disinfectants. Literature about antibiotic/disinfectant cross-resistance is inconclusive; some studies showed no apparent connection between resistance to antibiotics and resistance to disinfectants (17, $18,31)$, while some found a significant correlation $(14,22)$, some found correlations with certain types of antibiotic but not with others (16), and some concluded that crossresistance was possible (32). We opted for grouping the $A$. baumannii isolates into sensitive and resistant and for comparing their mean values rather than comparing the 


\begin{tabular}{|c|c|c|c|c|}
\hline \multirow[t]{2}{*}{ Isolate } & \multicolumn{2}{|c|}{ XDR } & \multicolumn{2}{|c|}{ Sensitive } \\
\hline & MBC (BAC) & $\mathrm{MBC}(\mathrm{CH})$ & MBC (BAC) & $\mathrm{MBC}(\mathrm{CH})$ \\
\hline ATCC & & & 25 & 50 \\
\hline EU1 & 25 & 50 & & \\
\hline EU2 & 100 & 100 & & \\
\hline ST4 & & & 100 & 100 \\
\hline ST10 & 50 & 25 & & \\
\hline IN12 & 25 & 50 & & \\
\hline IN21 & & & 25 & 50 \\
\hline EF4 & 50 & 100 & & \\
\hline Meantsd & $50 \pm 31$ & $65 \pm 34$ & $50 \pm 43$ & $67 \pm 29$ \\
\hline
\end{tabular}

Figure 7 Comparison of minimal bactericidal concentrations (MBCs) of benzalkonium chloride (BAC) and chlorhexidine digluconate (CH) between sensitive and extensively drug-resistant (XDR) A. baumannii isolates; Curly brackets mark the compared pairs tested with Student's t-test

MICs of specific antibiotics with the MICs of specific disinfectants, as we believe that such generalisation best represents real-life conditions, since the A. baumannii isolates described here were either multidrug-resistant or sensitive.

\section{Antibiotic susceptibility and biofilm formation}

We found no significant difference in the biofilmforming capacity between the multidrug-resistant and sensitive isolates. However, our study included only nine isolates, and the results are indicative at best. In contrast, a recent, much more comprehensive study of $272 \mathrm{~A}$. baumannii isolates showed that MDR and XDR isolates tended to form weaker biofilms than sensitive strains (33).

\section{CONCLUSION}

Our results suggest that disinfectant/surface material interactions could play an important role in the survival of A. baumannii biofilms on ceramics and that ceramic surfaces may be an important source of infection in hospital environments. They also underline the imperative to comply to manufacturer instructions during chemical disinfection. Our future research should look into the actual $A$. baumannii contamination of hospital bathrooms or showers and test new, hopefully more efficient methods of disinfection.

\section{Acknowledgments}

This work was funded by the Croatian Science Foundation (project no. IP-2014-09-5656). We wish to thank Mrs Renata Horvat for allowing us to publish the photograph of the experimental setup.

\section{REFERENCES}

1. McConnell M, Actis L, Pachón J. Acinetobacter baumannii: human infections, factors contributing to pathogenesis and animal models. FEMS Microbiol Rev 2013;37:130-55. doi: 10.1111/j.1574-6976.2012.00344.x

2. Peleg AY, Scifert H, Paterson DL. Acinetobacter baumannii: emergence of a successful pathogen. Clin Microbiol Rev 2008;21:538-82. doi: 10.1128/CMR.00058-07

3. Wang C, Wang J, Pan H, Hu W, Li Y. Multidrug resistance and biofilm formation contribute to the nosocomial infections caused by Acinetobacter baumannii. In: Méndez-Vilas A, editor. The battle against microbial pathogens: basic science, technological advances and educational programs. Vol. 1. Badajoz: Formatex Research Center; 2015. p. 452-61.

4. Lee CR, Lee JH, Park M, Park KS, Bae IK, Kim YB, Cha CJ, Jeong BC, Lee SH. Biology of Acinetobacter baumannii: pathogenesis, antibiotic resistance mechanisms, and prospective treatment options. Front Cell Infect Microbiol 2017;7:55. doi: 10.3389/fcimb.2017.00055

5. Longo F, Vuotto C, Donelli G. Biofilm formation in Acinetobacter baumannii. New Microbiol 2014;37:119-27. PMID: 24858639

6. Bridier A, Briandet R, Thomas V, Dubois-Brissonnet F. Resistance of bacterial biofilms to disinfectants: a review. B iofouling 2011;27:1017-32. doi : 10.1080/08927014.2011.626899

7. Espinal P, Marti S, Vila J. Effect of biofilm formation on the survival of Acinetobacter baumannii on dry surfaces. J Hosp Infect 2012;80:56-60. doi: 10.1016/j.jhin.2011.08.013

8. Gayoso CM, Mateos J, Mendez JA, Fernandez-Puente P, Rumbo C, Tomas M, Martínez de Ilarduya O, Bou G. Molecular mechanisms involved in the response to desiccation stress and persistence in Acinetobacter baumannii. J Proteome Res 2014;13:460-76. doi: 10.1021/ pr400603f 
9. Gaddy JA, Actis LA. Regulation of Acinetobacter baumannii biofilm formation. Future Microbiol 2009;4:273-8. doi: 10.2217/fmb.09.5

10. Vickery K, Deva A, Jacombs A, Allan J, Valente P, Gosbell IB. Presence of biofilm containing viable multiresistant organisms despite terminal cleaning on clinical surfaces in an intensive care unit. J Hosp Infect 2012;80:52-5. doi: 10.1016/j.jhin.2011.07.007

11. Liu WL, Liang HW, Lee MF, Lin HL, Lin YH, Chen CC, Chang PC, Lai CC, Chuang YC, Tang HJ. The impact of inadequate terminal disinfection on an outbreak of imipenemresistant Acinetobacter baumannii in an intensive care unit. PLoS One 2014;9:e107975. doi: 10.1371/journal. pone. 0107975

12. Lanjri S, Uwingabiye J, Frikh M, Abdellatifi L, Kasouati J, Maleb A, Bait A, Lemnouer A, Elouennass M. In vitro evaluation of the susceptibility of Acinetobacter baumannii isolates to antiseptics and disinfectants: comparison between clinical and environmental isolates. Antimicrob Resist Infect Control 2017;6:36. doi: 10.1186/s13756-017-0195-y

13. Sebit B, Aksu B, Karahasan Yagci A. Biofilm production and biocidal efficacy in multidrug-resistant Pseudomonas aeruginosa and Acinetobacter baumannii isolates. Int $\mathrm{J}$ Antisep Disinfect Steril 2016;1:7-12. doi: 10.14744/ ijads.2016.08208

14. Kawamura-Sato K. Wachino J, Kondo T, Ito H, Arakawa Y. Correlation between reduced susceptibility to disinfectants and multidrug resistance among clinical isolates of Acinetobacter species. Antimicrob Chemother 2010;65:197583. doi: $10.1093 / \mathrm{jac} / \mathrm{dkq} 227$

15. Babaei MR, Sulong A, Hamat RA, Nordin SA, Neela VK. Extremely high prevalence of antiseptic resistant Quaternary Ammonium Compound $\mathrm{E}$ gene among clinical isolates of multiple drug resistant Acinetobacter baumannii in Malaysia. Ann Clin Microbiol Antimicrob 2015;14:11. doi: 10.1186/ s12941-015-0071-7

16. Ali NE, Morsi SS, Elgohary EA. Association between antibiotics and disinfectants resistance profiles among Acinetobacter baumannii isolates in Zagazig University Hospitals intensive care unit. Life Sci J 2014;11:1-8.

17. Martró E, Hernández A, Ariza J, Domínguez MA, Matas L, Argerich MJ, Martin R, Ausina V. Assessment of Acinetobacter baumannii susceptibility to antiseptics and disinfectants. J Hosp Infect 2003;55:39-46. doi: 10.1016/S01956701(03)00220-2

18. Chalbaud A, Ramos Y, Alonso Y. Antibiotic and disinfectant resistance in Acinetobacter baumannii genotyped isolates from the Caracas University Hospital. In: Mendez-Vilas A, editor. Microbes in applied research: current advances and challenges. Singapore: World Scientific Publishing Co. Pte Ltd.; 2011. p. 481-5.

19. Hrenovic J, Goic-Barisic I, Kazazic S, Kovacic A, Ganjto M, Tonkic M. Carbapenem-resistant isolates of Acinetobacter baumannii from municipal wastewater treatment plant, Croatia, 2014. Euro Surveill 2016;21:pii=30195. doi: 10.2807/1560-7917.ES.2016.21.15.30195

20. Goic Barisic I, Towner KJ, Kovacic A, Sisko Kraljevic K, Tonkic M, Novak A, Punda-Polic V. Outbreak in Croatia caused by a new carbapenem-resistant clone of Acinetobacter baumannii producing OXA-72 carbapenemase. J Hosp Infect 2011;77:368-9. doi: 10.1016/j.jhin.2010.12.003
21. Tyski S, Bocian E, Grzybowska W. Reduction of the neutralisation time during antimicrobial activity testing of disinfectants according to European standards. Rocz Panstw Zakl Hig 2013;64:111-5. PMID: 23987079

22. Buffet-Bataillon S, Branger B, Cormier M, Bonnaure-Mallet $\mathrm{M}$, Jolivet-Gougeon A. Effect of higher minimum inhibitory concentrations of quaternary ammonium compounds in clinical E. coli isolates on antibiotic susceptibilities and clinical outcomes. J Hosp Infect 2011;79:141-6. doi: 10.1016/j.jhin.2011.06.008

23. European Committee on Antimicrobial Susceptibility Testing (EUCAST). http://www.eucast.org/clinical_breakpoints/

24. Magiorakos AP, Srinivasan A, Carey RB, Carmeli Y, Falagas ME, Giske CG, Harbarth S, Hindler JF, Kahlmeter G, OlssonLiljequist B, Paterson DL, Rice LB, Stelling J, Struelens MJ, Vatopoulos A, Weber JT, Monnet DL. Multidrug-resistant, extensively drug-resistant and pandrug-resistant bacteria: an international expert proposal for interim standard definitions for acquired resistance. Clin Microbiol Infect 2012;18:26881. doi: 10.1111/j.1469-0691.2011.03570

25. Célia Maria Carvalho Pereira Araújo Romão, Faria YN, Pereira LR, Asensi MD. Susceptibility of clinical isolates of multiresistant Pseudomonas aeruginosa to a hospital disinfectant and molecular typing. Mem Inst Oswaldo Cruz 2005;100:541-8. doi: 10.1590/S0074-02762005000500015

26. Pour NK, Dusane DH, Dhakephalkar PK, Zamin FR, Zinjarde SS, Chopade BA. Biofilm formation by Acinetobacter baumannii strains isolated from urinary tract infection and urinary catheters. FEMS Immunol Med Microbiol 2011;62:328-38. doi: 10.1111/j.1574-695X.2011.00818.x

27. Egington PJ, Holah J, Allison DG, Handley PS, Gilbert P. Changes in the strength of attachment of micro-organisms to surfaces following treatment with disinfectants and cleansing agents. Lett Appl Microbiol 1998;27:101-5. doi: 10.1046/j.1472-765X.1998.00390.x

28. Lehtola MJ, Miettinen IT, Lampola T, Hirvonen A, Vartiainen T, Martikainen PJ. Pipeline materials modify the effectiveness of disinfectants in drinking water distribution systems. Water Res 2005;39:1962-71. doi: 10.1016/j.watres.2005.03.009

29. Volkow P, Sánchez-Girón F, Rojo-Gutiérrez L, CornejoJuárez P. Hospital-acquired waterborne bloodstream infection by Acinetobacter baumannii from tap water. Infect Dis Clin Pract 2013;21:405-6. doi: 10.1097/IPC.0b013e31827f44d4

30. Lindford A, Kiuru V, Anttila VJ, Vuola J. Successful eradication of multidrug resistant Acinetobacter in the Helsinki burn centre. J Burn Care Res 2015;36:595-601.

31. Guimarães MA, Tibana A, Nunes MP, Netto dos Santos KR. Disinfectant and antibiotic activities: a comparative analysis in Brazilian hospital bacterial isolates. Braz J Microbiol 2000;31:193-9. doi: 10.1590/S1517-83822000000300008

32. Russell AD, Tattawasart U, Maillard JY, Furr JR. Possible link between bacterial resistance and use of antibiotics and biocides. Antimicrob Agents Chemother 1998;42:2151. PMCID: PMC105894

33. Qi L, Li H, Zhang C, Liang B, Li J, Wang L, Du X, Liu X, Qiu S, Song H. Relationship between antibiotic resistance, biofilm formation, and biofilm-specific resistance in Acinetobacter baumannii. Front Microbiol 2016;7:483. doi: 10.3389/fmicb.2016.00483 
Smanjena osjetljivost na dezinficijense bakterije Acinetobacter baumannii u obliku biofilma na staklu i keramici

Vrsta Acinetobacter baumannii prepoznata je kao trenutačno vodeći uzročnik bolničkih infekcija sa smrtnim ishodom. Trajna prisutnost $A$. baumannii u bolnicama posljedica je ponajviše otpornosti na antibiotike te sposobnosti ove bakterije da stvara biofilm. U radu je testirana osjetljivost biofilma kliničkih i okolišnih izolata vrste A. baumannii na najčešće korištene dezinficijense, benzalkonijev klorid i klorheksidin. Predložena je nova metoda za uzgoj biofilma na keramičkim pločicama te su rezultati uspoređeni s biofilmom koji je nastao na staklu. Bakterije unutar biofilma bile su otporne na dezinficijense; pri koncentraciji dezinficijensa koja je potpuno uništila planktonske bakterije, unutar biofilma preživjelo je više od $50 \%$ populacije, čak i nakon petominutnog izlaganja dezinficijensima. Značajno je opažanje da su bakterije u obliku biofilma na keramici znatno otpornije na dezinficijense od bakterija u obliku biofilma na staklu, iako je brojnost bakterija bila podjednaka. Navedeni rezultati upućuju na zaključak da je međudjelovanje materijala i dezinficijensa važan čimbenik koji određuje učinkovitost dezinfekcije. Sposobnost stvaranja biofilma na keramičkim površinama moguće je ishodište i značajno stanište bakterija $A$. baumannii u bolničkom okružju.

KLJUČNE RIJEČI: bolničke infekcije; dezinfekcija; otpornost na antibiotike; surfaktanti 